\title{
Ichthyofaunal diversity in snow-fed Mardi Stream of Gandaki River, Central Nepal
}

\author{
NEETI CHAPAGAIN ${ }^{1}$, NARESH PANDEY ${ }^{2, \boldsymbol{v}}$, PRABHA CHITRAKAR ${ }^{1}$ \\ ${ }^{1}$ Department of Zoology, Amrit Campus, Tribhuvan University. Lainchaur, Kathmandu 44600, Nepal \\ ${ }^{2}$ Central Department of Zoology, Institute of Science and Technology, Tribhuvan University. Kritipur, Kathmandu 44613, Nepal. \\ Tel./fax.: +977-9841080317, ‘email: pandeynaresh25@gmail.com, sneeti077@gmail.com
}

Manuscript received: 18 February 2021. Revision accepted: 29 April 2021.

\begin{abstract}
Chapagain N, Pandey N, Chitrakar P. 2021. Ichthyofaunal diversity in snow-fed Mardi Stream of Gandaki River, Central Nepal. Biodiversitas 22: 2940-2948. This study assessed site-wise and season-wise diversity and investigated the potential environmental correlates of ichthyofaunal assemblage in snow-fed Mardi Stream of central Nepal by extensive fieldworks from June 2018 to April 2019. The ichthyofaunal diversity and community structure in the hill streams of the Nepal Himalaya are understudied. A total of 1850 individual fish belonging to 3 orders, 3 families, 9 genera, and 10 species were collected. Cypriniformes emerged as the most species-rich order, accounting for $92.6 \%$ of the total species. Based on Similarity Percentage (SIMPER) analysis, the major contributing species were Schizothorax richardsonii (27.58\%), Garra annandalei (26.3\%), and Naziritor chelynoides (10.82\%). Diversity indices were found higher in summer season and downstream areas. Results from Generalized Linear Model (GLM) and Canonical Correspondence Analysis (CCA) revealed that $\mathrm{pH}$, Dissolved Oxygen (DO), water temperature and water velocity had significant relationship with fish assemblages. The fish assemblages along the gradient of the stream may be interrupted due to climate factors and anthropogenic disturbances. This study provides baseline data on hill stream fishes of Mardi Stream which might be helpful for implementation of conservation approaches.
\end{abstract}

Keywords: Environmental variables, fish assemblages, hill stream, ichthyofaunal diversity, Mardi Stream

\section{INTRODUCTION}

Freshwater habitats cover about $0.1 \%$ of Earth's surface, however, they provide habitat for approximately $10 \%$ of all animal species (Balian et al. 2007). Numerous streams and lakes are known to be biodiversity hotspots (Strayer and Dudgeon 2010), and understanding the biogeography and ecology of freshwater is crucial for biodiversity conservation and management especially in the context of ongoing and projected climate and land cover change (Morrongiello et al. 2011; Knouft and Ficklin 2017; Benateau et al. 2019). Freshwater fishes are known as the most threatened group of vertebrates (Reid et al. 2013). Obtaining functional knowledge of the response of populations and communities to environmental variation and disturbance on a temporal and spatial scale is important in fish ecology (Blanchet et al. 2014; Mondal and Bhat 2020). The environmental variables like water temperature, depth, water velocity, substrate, conductivity, alkalinity, dissolved oxygen, and $\mathrm{pH}$ play a significant role in shaping ichthyofaunal richness patterns and community structure (Tongnunui et al. 2016; Kautza and Sullivan 2012; Akhi et al. 2020; Limbu et al. 2020). Fish assemblages are also influenced by riparian vegetation, which provides additional food and aquatic refuges for small fish species (Virgilio et al. 2018; Carniatto et al. 2020).

In past decades, research on mountainous rivers has concentrated on developed countries, such as those in Europe and North America (Fraser et al. 2014; Wood et al. 2014). South Asia and Himalayas are well known for their water resources and freshwater biodiversity (Balian et al. 2007; Taylor et al. 2014). Freshwater fishes account for almost $1 / 4$ of all the world's vertebrate species (WWF International 2021). The freshwater biodiversity is plummeting at twice the rate of biodiversity in the oceans and forests and in case of freshwater fish, there are collapsing populations (Vaughn 2010; World Wildlife Fund 2021). Almost one-third of all freshwater fish are under threat of extinction (WWF International 2021). Sixteen freshwater fish species have been declared extinct in 2020 alone (BBC 2021). Climate change due to global warming (Arnell and Gosling 2013; Comte and Olden 2017; Barbarossa et al. 2021) and anthropogenic activities are major contributing factors for this crisis, poorly planned dams, water pollution, overfishing, and introduction of invasive species are devastating freshwater fish populations (Liermann et al. 2012; Dodds et al. 2013; Bukola et al. 2015; Li et al. 2018).

Nepal contains large numbers of freshwater species, including endemics, and has a remarkable turnover in species over short distance. The most unique feature of Nepal's freshwater diversity is the transition from alpine to tropical ecosystems over very short distances. Nepal is globally important in terms of freshwater biodiversity (Taylor et al. 2014). Despite its global and local significance, freshwater biodiversity in Nepal has received much less attention than terrestrial biodiversity (Dudgeon 2000). In context to fish, the study on hill stream fish diversity is in its initial stage, and only a limited number of studies on mountainous streams are available (Shrestha 
1981; Edds 1993; Limbu et al. 2020). However, those researches did not state which variables contribute most to bring variations in fish assemblage. The knowledge on the interaction between fish assemblage and environmental variables in-stream habitat can be useful for fish biodiversity conservation and river rehabilitation (Dudgeon 2005; Pokharel et al. 2018).

Mardi Stream (MS) is a snow-fed stream having a unique lotic water ecosystem characterized by rocky and gravel bottoms. The upstream region is slightly gradients and characterized by shallow, riffles and rapids whereas, the downstream region is flat with large agricultural field and flood plain on both sides. This diverse topography and habitat support various hill stream fishes and freshwater biota. The natural habitat of the MS is degrading due to several factors like overexploitation of fish resources, removal of bottom substrates, heavy flooding, and construction of hydropower dams. Only a few studies have been carried out in the MS (Shrestha and Shreshta 2008; Pokharel et al. 2018) but no recent study has been done. Therefore, this study was carried out in the MS aiming to assess (i) fish community structure, (ii) site-wise and season-wise richness, abundance, and diversity, (iii) investigate the potential environmental correlates of ichthyofaunal diversity patterns in the MS.

\section{MATERIALS AND METHODS}

\section{Study area}

MS is a snow-fed stream originated from Mardi Himal, a southern summit of $5578 \mathrm{~m}$ above sea level (asl) of Annapurna mountain range. It extends about $25 \mathrm{~km}$ in length and flows downward towards south-east direction. It is one of the major tributaries of the Seti Gandaki River. Four sampling sites were selected based on confluence point and human disturbances, and designed as I, II, III, and IV sampling sites respectively (Figure 1; Table 1).

\section{Sampling}

Seasonal sampling was carried out to cover all four seasons (Summer in June 2018, Autumn in October 2018, Winter in January 2019, and Spring in April 2019). Sample collection was done daily in above mentioned seasons. For the documentation of ichthyofauna, collection was done using gill net, cast net, and locally available mosquito nets. Gillnet (mesh size $1.2 \times 1.2 \mathrm{~cm}, \mathrm{~L} \times \mathrm{B}=12 \mathrm{~m} \times 1.5 \mathrm{~m}$ ) was fixed during late evening hours (17:00-18:00 hours) and recovered in early morning (5:00-6:00 hours). Cast net of mesh size ranging from $5 \mathrm{~mm}$ to $8 \mathrm{~mm}, 25-30$ feet long, and 3.5-5 feet width was used. Four separate and sequential efforts were made for sampling. Effort (one person, casting net 20 times, covering an area about 200m) was kept constant. In addition to this, locally available mosquito nets were also employed. These fishing gears were used within 200-250 $\mathrm{m}$ area of each sampling site for 2 hours at 7-9 am. The fishes were collected from stream with the help of local fishermen proficient in this occupation.

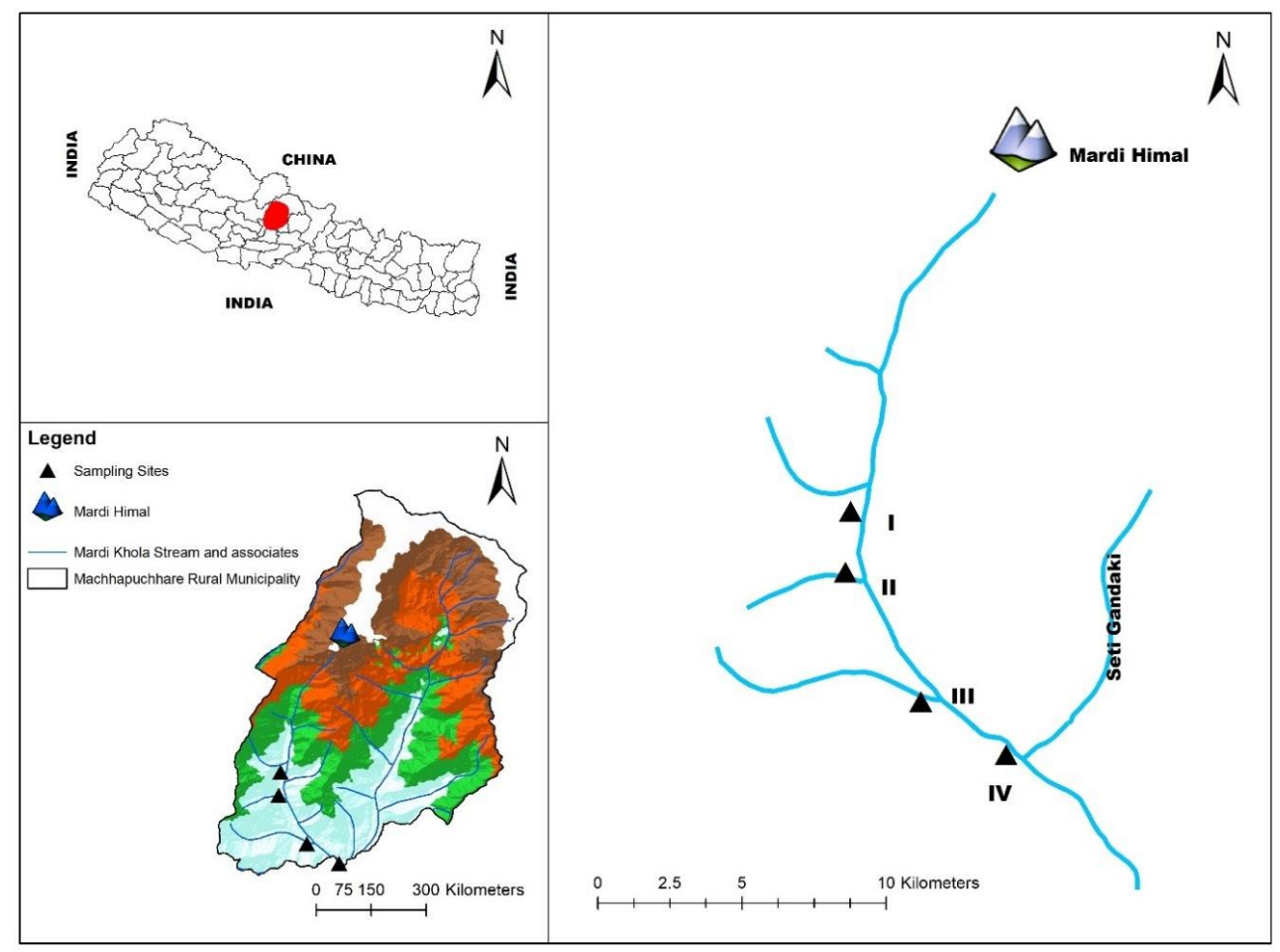

Figure 1. Map of the study area and sampling sites in the Mardi Stream, Nepal 
Table 1. Physical characteristics and morphological description of the sampling sites

\begin{tabular}{llccl}
\hline \multicolumn{1}{c}{ Sampling sites } & \multicolumn{1}{c}{ Substrate } & Longitude/Latitude & $\begin{array}{c}\text { Altitude } \\
\text { (masl) }\end{array}$ & Additional information \\
\hline Site I (Saitighatta) & Sand, gravels, pebble, boulders & $83.8827^{\circ} \mathrm{E}$ and $28.37082^{\circ} \mathrm{N}$ & 1325 & $\begin{array}{l}\text { Encroachment due to } \\
\text { hydropower project }\end{array}$ \\
& & & & \\
Site II (Lumre) & Sand, gravels, pebble, boulders & $83.8811^{\circ} \mathrm{E}$ and $28.3518^{\circ} \mathrm{N}$ & 1200 & Confluence with Pau Stream \\
Site III (Edi Dovan) & Sand, gravels, pebble, boulders & $83.9047^{\circ} \mathrm{E}$ and $28.3115^{\circ} \mathrm{N}$ & 1080 & Confluence with Edi Stream \\
Site IV (Seti Dovan) & Sand, gravels, pebble, boulders & $83.9313^{\circ} \mathrm{E}$ and $28.2949^{\circ} \mathrm{N}$ & 1030 & Confluence with Seti-Gandaki \\
\hline
\end{tabular}

Species richness and number of captured individuals of each species were recorded. About 10-15\% of captured individuals of each species were preserved as specimens, others were identified, counted and released unharmed. Before preserving in $10 \%$ formalin solution in plastic jars, fish samples were photographed and the preserved specimen was brought to the Department of Zoology, Amrit Science Campus, Kathmandu, Nepal for further identification. Standard keys available in print were used for fish identification (Talwar and Jhingran 1991; Shrestha, T. K. 2008).

\section{Environmental variables}

Water samples of the MS were collected during morning time (7:00 am to 9:00 am) and were analyzed in the field. Environmental variables like water temperature, dissolved oxygen (DO), $\mathrm{pH}$, alkalinity and water velocity were measured. Water temperature $\left({ }^{\circ} \mathrm{C}\right)$ was measured using a digital thermometer (Hanna, HI98501, UK) avoiding direct sunlight and placing it in the water at a depth of one foot for 60 seconds. The Winkler titrimetric method was used to calculate DO $(\mathrm{mg} / \mathrm{l})$, while $\mathrm{pH}$ was calculated using a $\mathrm{pH}$ meter (HI98107, Hanna, UK). To determine alkalinity, titration methods using alkalinity indicators (phenolphthalein and methyl orange) were used. Water velocity was calculated using the float method (Dobriyal et al. 2017; Abed 2021).

\section{Data analysis}

The following diversity indices were calculated to understand ichthyofaunal diversity in the MS.

\section{Shannon-wiener Diversity Index}

$$
\mathrm{H}^{\prime}=-\sum S i=1 P i * \log P i
$$

Where, $\mathrm{S}$ is the total number of species and $P i$ is the relative cover of $i^{\text {th }}$ of species.

\section{Simpson Dominance Index}

$$
\mathrm{C}=\sum_{i=1}^{s}\left(\frac{n i}{N}\right)^{2}
$$

Where, $\mathrm{n}_{\mathrm{i}}$ is the number of individuals in each species, $\mathrm{N}$ is a total number of individuals and $\mathrm{S}$ is a total number of species.

\section{Evenness Index}

$$
\mathrm{E}=H^{\prime} / \log S
$$

Where, H' is the Shannon-Wiener diversity index and S is the total number of species in sample.

To visualize the major contributing species, similarity percentage (SIMPER) analysis was performed. The effects of different environmental variables on fish species richness in the MS were tested by generalized linear model (GLM). In addition to that, the correlation between fish community structure and environmental variables was first tested by Detrended Correspondence Analysis (DCA). The axis length and eigenvalue acquired from DCA suggested that the linear model of Canonical Correspondence Analysis (CCA) was more applicable. Therefore, a direct multivariate ordination method based on a linear response of species to environmental gradients was applied using Canoco v.5.01 (Ter Braak and Smilauer 2002).

\section{RESULTS AND DISCUSSION}

A total of 1850 individual fish representing 10 species belonging to 3 orders, 3 families and 9 genera were recorded from the Mardi Stream. The fish in the MS account for $33.3 \%$ of the total species richness recorded in Seti Gandaki (Pokharel et al. 2018). During our study, globally vulnerable species like Schizothorax richardsonii, Naziritor chelynoides, and near-threatened species Neolissochilus hexagonolepsis were also recorded. This categorization may be useful for planning conservation strategies for genetic resources of ichthyofauna.

\section{Fish community structure}

The order Cypriniformes was found to be the most dominant order which comprised $92.6 \%$ followed by Siluriformes $5.6 \%$. Similarly, family Cyprinidae (92.6\%) was found dominating the ichthyofaunal community followed by Sisoridae family $(5.6 \%)$ (Table 2). Previous studies on hill streams found that fish community is dominated by order Cypriniformes (Ahmed et al. 2013; Shrestha 2019; Limbu et al. 2020).

\section{Richness, abundance, and diversity}

The highest number of species and individuals were recorded from site-III and the lowest was from site-I 
(Figure 2). Similar results were found in previous research with progressive increase in number of fish species downstream (Bhatt et al. 2012; Negi and Mamgain 2013). At the upstream sites, the lower species richness may be attributed to lower temperature, depth, width and nutrient availability. But, because of higher temperature, depth, width and changes in the impacts of urban factors, richness was higher at the downstream sites.

Highest number of species and individuals was recorded from summer season and lowest was found in spring season (Figure 3). Results of the study were consistent with other previous researches (Acharjee and Barat 2014; Prasad et al. 2020). Increased water temperature during summer, availability of fish food (macroinvertebrate, plankton) may contribute in upraising population and species richness. In addition, water discharge rises during the summer season due to constant rainfall from South-Asian summer monsoon, coinciding with increased movement and upstream spawning migrations of many fishes. Similar forms of spawning migrations occur with increased discharge of rivers in Nepal (Edds 1993) and from other parts of the world (Chapman et al. 2012; Baker et al. 2020). Based on similarity percentage (SIMPER) analysis, it was found that major contributing species were Schizothorax richardsonii (27.58\%), Garra annandalei (26.30\%), Naziritor chelynoides (10.82\%), and Pseudecheneis sulcatus (7.8\%) (Table 3).
Table 2. List of fishes collected from Mardi Stream, Nepal

\begin{tabular}{lll}
\hline \multicolumn{1}{c}{ Order } & Family & \multicolumn{1}{c}{ Species } \\
\hline Cypriniformes & Cyprinidae & $\begin{array}{l}\text { Schizothorax richardsonii } \\
\text { Schizothorax plagiostomus } \\
\end{array}$ \\
& & Garra annandalei \\
& & Barilius bendelisis \\
& Neolissochilus hexagonolepis \\
& & Puntius sophore \\
& & Naziritor chelynoides \\
& & Danio dangila \\
Siluriformes & Sisoridae & Pseudecheneis sulcatus \\
Anabantiformes & Channidae & Channa orientalis \\
\hline
\end{tabular}

Table 3. Average similarity and discriminating fish using SIMPER analysis

\begin{tabular}{clc}
\hline Code & \multicolumn{1}{c}{ Species } & Contribution (\%) \\
\hline C1 & Schizothorax richardsonii & 27.58 \\
C2 & Garra annandalei & 26.3 \\
C8 & Naziritor chelynoides & 10.82 \\
C5 & Pseudecheneis sulcatus & 7.8 \\
C3 & Barilius bendelisis & 6.46 \\
C9 & Danio dangila & 5.53 \\
C10 & Schizothorax plagiostomus & 5.51 \\
C4 & Neolissochilus hexagonolepis & 4.85 \\
C6 & Channa orientalis & 3.25 \\
C7 & Puntius sophore & 1.87 \\
\hline
\end{tabular}
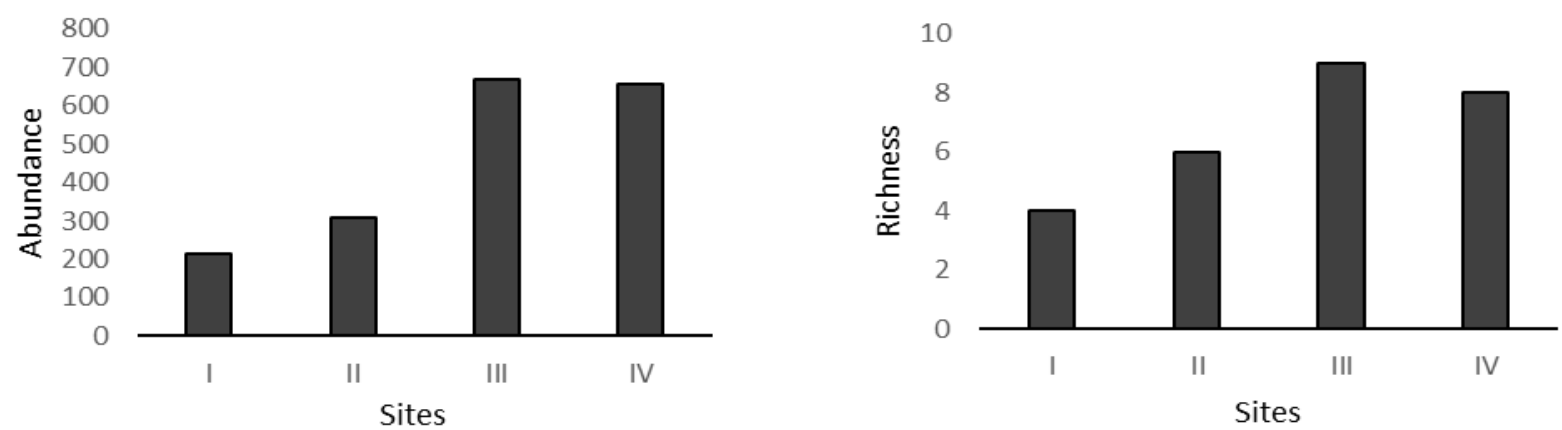

Figure 2. Site-wise abundance and richness of fish species recorded in Mardi Stream, Nepal
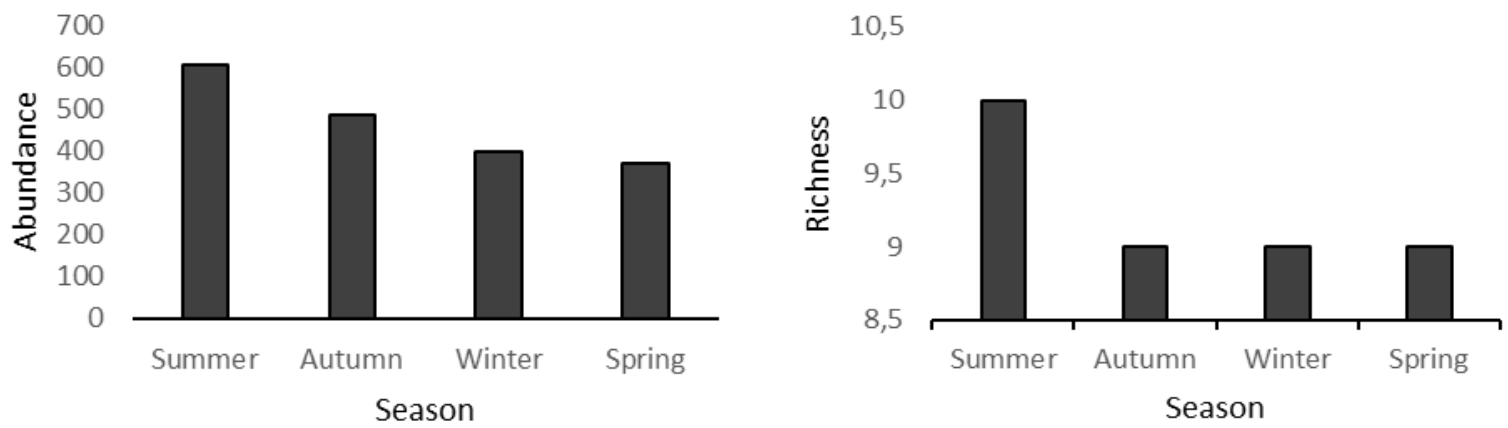

Figure 2. Site-wise abundance and richness of fish species recorded in Mardi Stream, Nepal 
Site-wise and season-wise ichthyofaunal diversity indices observed in the MS were calculated (Table 4). The highest Shannon-Weiner index (1.85) was found at site-III and lowest (0.66) was found at site-I. Highest ShannonWeiner Diversity index was found in spring season (1.86), whereas lowest was found during summer season (1.7). The Simpson index in different sites varies from 0.33 to 0.8 . The highest diversity index was recorded at site-III (0.8) and lowest was recorded at site-I (0.33). Highest Simpson diversity index was recorded in autumn (0.8) and lowest was recorded in summer (0.77). A diversity in assemblage of fish was observed along the gradient of the stream. Such diversity seems to be in an agreement with the "River Continuum Concept" which involves energy sources and their allocation (Acharjee and Barat 2014). This implies that there is availability of higher amounts of energy at lower altitudes as more solar radiation and other resources (such as minerals and water) are adequately present. Consequently, higher range in richness of species can be conveniently allowed at lower altitudes.

\section{Seasonal variation in environmental variables}

The diversity of ichthyofaunal distribution is influenced by seasonal variation at freshwater stream which reflected in varied physicochemical parameters of the water. The concentration of physicochemical parameters in all seasons is shown in (Table 5). During the study period, water temperature in $\mathrm{MS}$ showed some seasonal variation and ranged from $12^{\circ} \mathrm{C}$ to $25^{\circ} \mathrm{C}$. As expected, water temperature was the highest during summer season and the lowest during winter season. The highest water temperature value was recorded at site IV during summer season $\left(25^{\circ} \mathrm{C}\right)$ and the lowest temperature was at site I during winter season $\left(12^{\circ} \mathrm{C}\right)$. Several types of research have reported variation in temperature due to variation in altitude, which is characteristics features of streams originated from higher mountain (Sharma et al. 2007; Kumar et al. 2019; Limbu et al. 2020). The velocity of water fluctuated from $0.52 \mathrm{~m} / \mathrm{s}$ to $1.8 \mathrm{~m} / \mathrm{s}$. The highest water velocity $(1.8 \mathrm{~m} / \mathrm{s})$ was recorded at site IV during summer and the lowest $(0.52 \mathrm{~m} / \mathrm{s})$ at site III during winter season. $\mathrm{pH}$ was recorded in the range 8.1 to 9.5 , which indicated that water was alkaline in nature. Highest (9.5) was recorded at site II during spring and lowest (8.1) at site III during summer. Alkalinity plays important role for fish and aquatic life because it protects or buffers against pH changes (Subba et al. 2020). Alkalinity in MS ranged 15 to $80 \mathrm{mg} / \mathrm{l}$. Highest value (80 $\mathrm{mg} / \mathrm{l})$ was recorded at site IV during autumn and lowest (15 $\mathrm{mg} / \mathrm{l})$ was recorded at site I during winter. From welldocumented research, DO is a regulating parameter in stream ecology (Rajwa-Kuligiewicz et al. 2015; Keshtegar and Heddam 2018). DO concentration in water is inversely related to water temperature (Post et al. 2018). The DO values varied from 8.1 to $10.4 \mathrm{mg} / \mathrm{l}$. Highest was recorded at site I and lowest at site IV. High dissolved oxygen was observed during the winter season, which may be attributed to the high photosynthetic rate of the phytoplankton communities in clearwater resulting in higher concentration of dissolved oxygen ( $\mathrm{Xu}$ et al. 2016; Liu et al. 2020). Higher dissolved oxygen $(10.4 \mathrm{mg} / \mathrm{l})$ in winter season and lower oxygen $(8.1 \mathrm{mg} / \mathrm{l})$ in monsoon were recorded. Similar results were recorded in many rivers of Gangetic plain, India (Rani et al. 2011), several rivers of the Central Himalayas (Singh and Agarwal 2014), and headwater stream of Garhwal Himalaya (Sharma et al. 2016).

\section{Correlation between fish assemblage and environmental variables}

Several researchers (Edds 1993; Negi and Mamgain 2013; Pokharel et al. 2018; Huang et al. 2019) have documented correspondence between fish distribution and environmental variables and confirmed changes of fish assemblage along an upstream-downstream gradient. In this study among the tested environmental variables, the generalized linear model (GLM) showed different relations on fish richness pattern. The $\mathrm{pH}$, dissolved oxygen, water temperature and water velocity showed significant role in shaping the fish richness pattern in the MS (Table 6).

Table 4. Site-wise and season-wise fish faunal diversity indices in Mardi Stream, Nepal

\begin{tabular}{llccc}
\hline Categories & $\begin{array}{c}\text { Shannon- } \\
\text { Weiner } \\
\text { Index (H') }\end{array}$ & $\begin{array}{c}\text { Simpson } \\
\text { Dominance } \\
\text { Index }\end{array}$ & $\begin{array}{c}\text { Evenness } \\
\text { Index }\end{array}$ \\
\hline Sites & I & 0.66 & 0.335 & 0.145 \\
& II & 1.304 & 0.664 & 0.288 \\
& III & 1.853 & 0.801 & 0.3481 \\
& IV & 1.815 & 0.807 & 0.35 \\
Seasons & Summer & 1.86 & 0.79 & 0.35 \\
& Autumn & 1.83 & 0.8 & 0.34 \\
& Winter & 1.804 & 0.79 & 0.34 \\
& Spring & 1.7 & 0.77 & 0.33 \\
\hline
\end{tabular}

Table 5. Seasonal mean value of environmental variables recorded in Mardi Stream, Nepal

\begin{tabular}{|c|c|c|c|c|c|c|c|c|c|c|c|c|c|c|c|c|}
\hline \multirow{2}{*}{ Variables } & \multicolumn{4}{|c|}{ Summer } & \multicolumn{4}{|c|}{ Autumn } & \multicolumn{4}{|c|}{ Winter } & \multicolumn{4}{|c|}{ Spring } \\
\hline & I & II & III & IV & I & II & III & IV & I & II & III & IV & I & II & III & IV \\
\hline & 19 & 20 & 24 & 27 & 16 & 18 & 19 & 22 & 12 & 14 & 18 & 19 & 16 & 18 & 21 & 24 \\
\hline Velocity $(\mathrm{m} / \mathrm{s})$ & 1.47 & 1.25 & 1.14 & 1.8 & 1.5 & 1.2 & 0.83 & 0.9 & 1.2 & 1.07 & 0.52 & 0.58 & 1.6 & 1.39 & 0.6 & 1.57 \\
\hline $\mathrm{pH}$ & 9.1 & 9 & 8.1 & 8.3 & 8.4 & 9.1 & 8.7 & 8.81 & 9 & 9.2 & 8.7 & 8.83 & 9.1 & 9.5 & 8.8 & 8.6 \\
\hline Dissolved C & 8.9 & 8.86 & 8.21 & 8.1 & 10.12 & 9.82 & 9.24 & 8.91 & 10.4 & 10.25 & 9.8 & 9.4 & 9.2 & 9.12 & 8.82 & 8.74 \\
\hline Alkalinity $(\mathrm{mg} / \mathrm{l})$ & 20 & 20 & 30 & 35 & 50 & 60 & 60 & 80 & 15 & 20 & 20 & 30 & 30 & 35 & 25 & 25 \\
\hline
\end{tabular}


Table 6. Generalized linear model (GLM) with normal distribution and identity link function test showing the effects of different factors on fish richness pattern in Mardi Stream, Nepal

\begin{tabular}{lccc}
\hline \multicolumn{1}{c}{ Factors } & Slope (a) & Intercept (b) & $\boldsymbol{P}$-value \\
\hline $\mathrm{pH}$ & -0.078 & 9.272 & 0.006 \\
Dissolved Oxygen (DO) & -0.132 & 9.99 & 0.019 \\
Alkalinity & 2.049 & 23.02 & 0.232 \\
Water Temperature & 0.803 & 13.68 & 0.0003 \\
Velocity & -0.06471 & 1.53 & 0.049 \\
\hline Note: Values marked in & italics are & statistically & significant \\
at $P<0.05$. & & &
\end{tabular}

Dissolved oxygen (DO), $\mathrm{pH}$, and water velocity exhibited negative, but water temperature showed positive relationship with fish richness in the MS. This study recorded that maximum number of species were found in sites with lower DO, $\mathrm{pH}$ and water velocity i.e. downstream. Only few selective species such as Schizothorax richardsonii and S. plagiostomus with higher oxygen requirement were found in sites with higher DO, $\mathrm{pH}$, and water velocity i.e. upstream (Figure 4). Environmental variables like dissolved oxygen, $\mathrm{pH}$, and water velocity were found higher upstream and lower downstream. Our results were consistent with previous researches on hill streams ( $\mathrm{Bu}$ et al. 2010; Aryani et al. 2019).

The Monte-Carlo permutation test of significance of all canonical axes revealed significant relationship (Trace=
0.361, F-ratio $=3.557, \quad \mathrm{P}=0.002) . \quad$ The canonical correspondence analysis (CCA) showed that the fish species like Schizothorax richardsonii (c1) and $S$. plagiostomus (c10) were positively linked to dissolved oxygen, $\mathrm{pH}$ and water velocity but negatively related to water temperature. Fish species like Pseudecheneis sulcatus (c5) showed positive association with alkalinity. Likewise, species like Channa orientalis (c6), Naziritor chelynoides (c8) and Danio dangila (c9) showed positive association with water temperature but negative with water velocity, $\mathrm{pH}$, and dissolved oxygen.

In our study previously recorded few freshwater fish species like Nemacheilus corica and Barilius vagra were not found in entire study period. But, we found few new species like Puntius sophore and Danio dangila which were not recorded previously in this stream. Such type of change in community structure might be due to shift in species distribution range. This shift might be due to changes in hydrology as well as rise in water temperature likely due to global warming. Previous study showed that the annual mean water temperature in Mardi Khola was observed to be $19^{\circ} \mathrm{C}$ (Shrestha and Shreshta 2008). Following in the year 2014, the mean water temperature was observed $24 \pm 3^{\circ} \mathrm{C}$ (Shah 2014). However, he conducted the study in spring season only. And in both types of research, the time of recording water temperature was unclear. In our study, the mean water temperature was recorded $19.2 \pm 3^{\circ} \mathrm{C}$

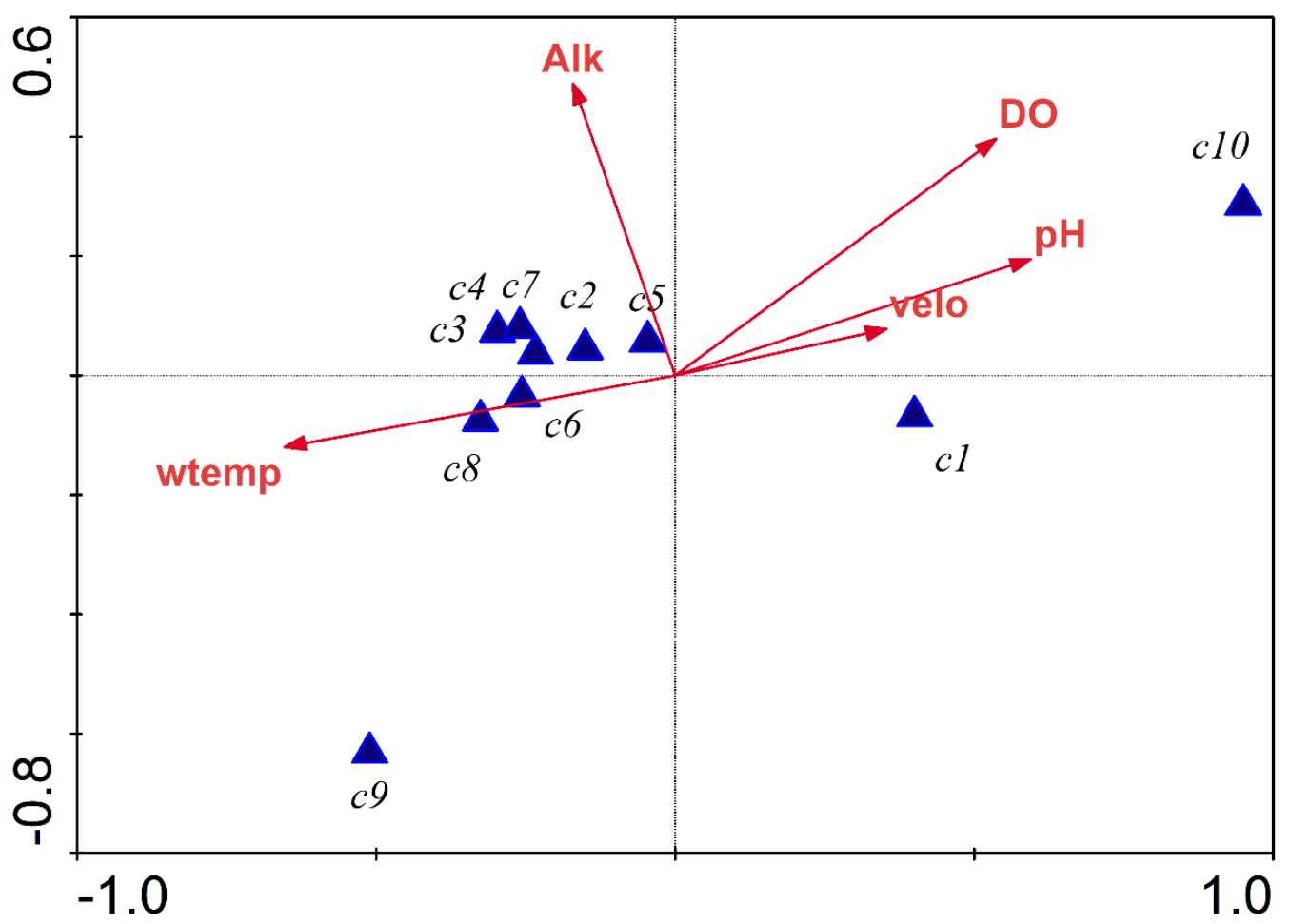

Figure 4. CCA ordination diagram (biplot) showing species response to different environmental variables. Note: DO: Dissolved Oxygen, velo: Water Velocity, Alk: Alkalinity, wtemp: Water Temperature 
Thus, the annual rise in water temperature could be expected. In another context, the temperature of water bodies like pond, river, and stream is governed by the interaction of natural environmental process like atmospheric temperature (Piccolroaz et al. 2013; O'Reilly et al. 2015), solar radiation (Schmid and Köster 2016), or conduction from the soil, etc. Result from the data of longterm trend analysis of average temperature change at Lumle meteorological station, Kaski (nearest meteorological station) showed increasing trend in average atmospheric temperature (WWF Nepal 2013). Conclusively, from the above researches, we can infer that the mean water temperature of Mardi Stream is gradually increasing. Globally, in recent years many studies have shown that freshwater fish species could greatly change their current distribution in response to climate change (Booth et al. 2011; Comte et al. 2013; Fogarty et al. 2017; Carosi et al. 2019).

Anthropogenic disturbances such as unscientific construction of roads in the watershed, extraction of boulders and sand mining, extensive fishing activities using electrofishing and lethal chemical, and construction of hydropower dams were few observed harmful activities. These practices contribute to natural habitat degradation, which eventually alters the composition of the riverine ecosystem (Morrongiello et al. 2011; Sarkar et al. 2012; (Keskar et al. 2017; Liu, X. et al. 2018).

The study from the MS found that Cyprinidae and order Cypriniformes were dominant in ichthyofaunal community. Diversity indices revealed that higher fish diversity exists on downstream sites. Environmental variables like water temperature, dissolved oxygen, $\mathrm{pH}$ and water velocity have a significant influence on structuring fish assemblage and distribution. The fish species richness in the study area accounts for vital proportion i.e. 21.7\% (Prasad et al. 2020) and $33.3 \%$ (Pokharel et al. 2018) of total fish species recorded in Seti Gandaki. Despite this ichthyofaunal importance, it is facing certain anthropogenic disturbances and effects of climate change. Therefore, a comprehensive survey focusing on the fish species-habitat relationship along with the impacts of climate change and anthropogenic disturbances is necessary, which might play a vital role in the development of baseline information and the implementation of conservation approaches in hill streams.

\section{ACKNOWLEDGMENTS}

We would like to thank the Department of Zoology, Amrit Campus, Kathmandu and the Department of Zoology, Prithivi Narayan Campus, Pokhara for providing equipment and laboratory facilities. We would like to extend our gratitude to Dr. Laxman Khanal, Central Department o Zoology, Tribhuvan University for his valuable suggestions during manuscript preparation. We thank Late Narayan Gautam, Jamuna Bhandari Gautam, Reeti Chapagain, Jashhang Limbu and local fishermen for their support during field visits and data collection. NC and NP performed field surveys, collected and analyzed data, and prepared the manuscript. PC supervised the research and provided inputs on manuscript preparation.

\section{REFERENCES}

Abed BS. 2021. Flow measurements in open channels using integratingfloats. J Eng 27 (1): 130-141. DOI: 10.31026/j.eng.2021.01.09.

Acharjee M, Barat S. 2014. Seasonal dynamics of ichthyodiversity in a hill stream of the Darjeeling Himalaya, West Bengal, India. J Threat Taxa 6 (14): 6635-6648. DOI: 10.11609/JoTT.03404.6635-48.

Ahmed ATA, Rahman MM, Mandal S. 2013. Biodiversity of hillstream fishes in Bangladesh. Zootaxa 3700 (2): 283-292. DOI: 10.11646/zootaxa.3700.2.6.

Akhi MM, Jewel MAS, Haque MA, Sarker BK, Khatun MS, Paul AK, Das SK. 2020. Multivariate approaches to determine the relationship between fish assemblage structure and environmental variables in Karatoya River, Bangladesh. Community Ecol 21: 171-181. DOI: 10.1007/s42974-020-00015-6.

Arnell NW, Gosling SN. 2013. The impacts of climate change on river flow regimes at the global scale. J Hydrol 486: 351-364. DOI: 10.1016/j.jhydrol.2013.02.010.

Aryani N, Suharman I, Azrita A, Syandri H, Mardiah A. 2019. Diversity and distribution of fish fauna of upstream and downstream areas at Koto Panjang Reservoir, Riau Province, Indonesia. F1000 Res 8: 1435 DOI: 10.12688/f1000research.19679.2

Baker N, Taylor M, Cowx I, Harvey J, Nunn A, Angelopoulos N, Baxter J. 2020. The response of river-resident fish to reservoir freshet releases of varying profiles intended to facilitate a spawning migration. Water Resour Res 56 (6): e2018WR024196. DOI: 10.1029/2018WR024196.

Balian EV, Segers H, Martens K, Lévéque C. 2007. The freshwater animal diversity assessment: An overview of the results. Freshw Anim Divers Assess 595: 627-637. DOI: 10.1007/978-1-4020-8259-7_61.

Barbarossa V, Bosmans J, Wanders N, King H, Bierkens MFP, Huijbregts MAJ, Schipper AM. 2021. Threats of global warming to the world's freshwater fishes. Nat Commun 12 (1): 1701. DOI: 10.1038/s41467021-21655-w.

BBC. 2021. Extinction: Freshwater Fish in 'catastrophic' Decline. Retrieved 3rd Dec 2021. https://www.bbc.com/news/scienceenvironment-56160756.

Benateau S, Gaudard A, Stamm C, Altermatt F. 2019. Climate Change and Freshwater Ecosystems: Impacts on Water Quality and Ecological Status. Federal Office for the Environment (FOEN), Bern, Switzerland. DOI: 10.5167/uzh-169641.

Bhatt JP, Manish K, Pandit MK. 2012. Elevational gradients in fish diversity in the Himalaya: Water discharge is the key driver of distribution patterns. PLoS One 7 (9): e46237. DOI: 10.1371/journal.pone.0046237.

Blanchet S, Helmus MR, Brosse S, Grenouillet G. 2014. Regional vs local drivers of phylogenetic and species diversity in stream fish communities. Freshw Biol 59 (3): 450-462. DOI: 10.1111/fwb.12277

Booth DJ, Bond N, Macreadie P. 2011. Detecting range shifts among Australian fishes in response to climate change. Mar Freshw Res 62 (9): 1027-1042. DOI: 10.1071/MF10270.

Bu H, Tan X, Li S, Zhang Q. 2010. Temporal and spatial variations of water quality in the Jinshui River of the South Qinling Mts., China. Ecotoxicol Environ Saf 73 (5): 907-913. DOI: 10.1016/j.ecoenv.2009.11.007.

Bukola D, Zaid A, Olalekan EI, Falilu A. 2015. Consequences of anthropogenic activities on fish and the aquatic environment. Poult Fish Wildl Sci 3:2. DOI: 10.4172/2375-446x.1000138.

Carniatto N, Cunha ER, Thomaz SM, Quirino BA, Fugi R. 2020. Feeding of fish inhabiting native and non-native macrophytes stands in a Neotropical reservoir. Hydrobiologia 847 (6): 1553-1563. DOI: 10.1007/s10750-020-04212-2.

Carosi A, Padula R, Ghetti L, Lorenzoni M. 2019. Endemic freshwater fish range shifts related to global climate changes: A long-term study provides some observational evidence for the Mediterranean area. Water 11 (11): 2349. DOI: 10.3390/w11112349.

Chapman B, Hulthén K, Brodersen J, Nilsson PA, Skov C, Hansson LA, Brönmark C. 2012. Partial migration in fishes: Causes and consequences. J Fish Biol 81 (2): 456-478. DOI: 10.1111/j.10958649.2012.03342.x. 
Comte L, Buisson L, Daufresne M, Grenouillet G. 2013. Climate-induced changes in the distribution of freshwater fish: Observed and predicted trends. Freshw Biol 58 (4): 625-639. DOI: 10.1111/fwb.12081.

Comte L, Olden JD. 2017. Climatic vulnerability of the world's freshwater and marine fishes. Nat Clim Chang 7 (10): 718-722. DOI: 10.1038/nclimate3382.

Dobriyal P, Badola R, Tuboi C, Hussain SA. 2017. A review of methods for monitoring streamflow for sustainable water resource management. Appl Water Sci 7 (6): 2617-2628. DOI: 10.1007/s13201-016-0488-y.

Dodds WK, Perkin JS, Gerken JE. 2013. Human impact on freshwater ecosystem services: A global perspective. Environ Technol 47 (16): 9061-9068. DOI: 10.1021/es4021052.

Dudgeon D. 2000. Large-scale hydrological changes in tropical Asia: Prospects for riverine biodiversity: The construction of large dams will have an impact on the biodiversity of tropical Asian rivers and their associated wetlands. BioSci 50 (9): 793-806. DOI: 10.1641/0006-3568(2000)050[0793:LSHCIT]2.0.CO;2.

Dudgeon D. 2005. River rehabilitation for conservation of fish biodiversity in monsoonal Asia. Ecol Soc 10 (2): 15. DOI 10.5751/es-01469-100215.

Edds DR. 1993. Fish assemblage structure and environmental correlates in Nepal's Gandaki River. Copeia 1993 (1): 48-60. DOI: $10.2307 / 1446294$

Fogarty HE, Burrows MT, Pecl GT, Robinson LM, Poloczanska ES 2017. Are fish outside their usual ranges early indicators of climate-driven range shifts? Glob Chang Biol 23 (5): 2047-2057. DOI: $10.1111 / \mathrm{gcb} .13635$.

Fraser DJ, Debes PV, Bernatchez L, Hutchings JA. 2014. Population size, habitat fragmentation, and the nature of adaptive variation in a stream fish. Proc R Soc B 281 (1790): 20140370. DOI: 10.1098/rspb.2014.0370.

Huang J, Huang L, Wu Z, Mo Y, Zou Q, Wu N, Chen Z. 2019 Correlation of fish assemblages with habitat and environmental variables in a headwater stream section of Lijiang River, China Sustainability 11 (4): 1135. DOI: 10.3390/su11041135.

Kautza A, Sullivan SMP. 2012. Relative effects of local-and landscapescale environmental factors on stream fish assemblages: Evidence from Idaho and Ohio, USA. Fundam Appl Limnol-Archiv furHydrobiol 180 (3): 259. DOI: 10.1127/1863-9135/2012/0282.

Keshtegar B, Heddam S. 2018. Modeling daily dissolved oxygen concentration using modified response surface method and artificial neural network: A comparative study. Neural Comput Appl 30 (10): 2995-3006. DOI: 10.1007/s00521-017-2917-8.

Keskar A, Raghavan R, Kumkar P, Padhye A, Dahanukar N. 2017 Assessing the sustainability of subsistence fisheries of small indigenous fish species: fishing mortality and exploitation of hillstream loaches in India. Aquat Living Resour 30: 13. DOI: 10.1051/alr/2016036.

Knouft JH, Ficklin DL. 2017. The potential impacts of climate change on biodiversity in flowing freshwater systems. Annu Rev Ecol Evol Syst 48: 111-133. DOI: 10.1146/annurev-ecolsys-110316-022803.

Kumar R, Raina A, Sharma N. 2019. Dataset on water quality characteristics of a hill stream in Bhaderwah, Jammu and Kashmir. Data Brief 26: 104462. DOI: 10.1016/j.dib.2019.104462.

Li Y, Tao J, Chu L, Yan Y. 2018. Effects of anthropogenic disturbances on $\alpha$ and $\beta$ diversity of fish assemblages and their longitudina patterns in subtropical streams, China. Ecol Freshw Fish 27 (1): 433 441. DOI: $10.1111 /$ eff.12358.

Liermann CR, Nilsson C, Robertson J, Ng RY. 2012. Implications of dam obstruction for global freshwater fish diversity. BioSci 62 (6): 539548. DOI: $10.1525 /$ bio.2012.62.6.5

Limbu JH, Bhurtel B, Adhikari A, GC P, Maharjan M, Sunuwar S. 2020 Fish community structure and environmental correlates in Nepal's Andhi Khola, Province No. 4, Syangja. Borneo J Resour Sci Technol 10 (2): 85-92. DOI: 10.33736/bjrst.2510.2020.

Liu G, He W, Cai S. 2020. Seasonal variation of dissolved oxygen in the Southeast of the Pearl River Estuary. Water 12 (9): 2475. DOI: $10.3390 / \mathrm{w} 12092475$

Liu X, Hu X, Ao X, Wu X, Ouyang S. 2018. Community characteristics of aquatic organisms and management implications after construction of Shihutang Dam in the Gangjiang River, China. Lake Reserv Manag 34 (1): 42-57. DOI: 10.1080/10402381.2017.1373716

Mondal R, Bhat A. 2020. Temporal and environmental drivers of fishcommunity structure in tropical streams from two contrasting regions in India PLoS One 15 (4): e0227354 DOI: 10.1371/journal.pone.0227354.

Morrongiello JR, Beatty SJ, Bennett JC, Crook DA, Ikedife DN, Kennard MJ, Pusey BJ. 2011. Climate change and its implications for Australia's freshwater fish. Mar Freshw Res 62 (9): 1082-1098. DOI: 10.1071/MF10308

Negi R, Mamgain S. 2013. Species diversity, abundance and distribution of fish community and conservation status of Tons river of Uttarakhand State, India. J Fish Aquat Sci 8 (5): 617-626. DOI: 10.3923/jfas.2013.617.626.

O'Reilly CM, Sharma S, Gray DK, Hampton SE, Read JS, Rowley RJ, Kraemer BM. 2015. Rapid and highly variable warming of lake surface waters around the globe. Geophys Res Lett 42 (24): 10773710781. DOI: 10.1002/2015GL066235.

Piccolroaz S, Toffolon M, Majone B. 2013. A simple lumped model to convert air temperature into surface water temperature in lakes. Hydrol Earth Syst Sci 17 (8): 3323-3338. DOI: 10.5194/hess-173323-2013.

Pokharel KK, Basnet KB, Majupuria TC, Baniya CB. 2018. Correlations between fish assemblage structure and environmental variables of the Seti Gandaki River Basin, Nepal. J Freshw Ecol 33 (1): 31-43. DOI: 10.1080/02705060.2017.1399170.

Post CJ, Cope MP, Gerard PD, Masto NM, Vine JR, Stiglitz RY, Mikhailova EA. 2018. Monitoring spatial and temporal variation of dissolved oxygen and water temperature in the Savannah River using a sensor network. Environ Monit Assess 190 (5): 1-14. DOI: 10.1007/s10661-018-6646-y.

Prasad A, Shrestha A, Limbu JH, Swar D. 2020. Spatial and temporal variation of fish assemblages in Seti Gandaki River, Tanahu, Nepal. Borneo J Resour Sci Technol 10 (2): 93-104. DOI: 10.33736/bjrst.2048.2020.

Rajwa-Kuligiewicz A, Bialik RJ, Rowiński PM. 2015. Dissolved oxygen and water temperature dynamics in lowland rivers over various timescales. J Hydrol Hydromech 63 (4): 353-363. DOI: 10.1515/johh2015-0041.

Rani N, Sinha RK, Prasad K, Kedia DK. 2011. Assessment of temporal variation in water quality of some important rivers in middle Gangetic plains, India. Environ Monit Assess 174 (1): 401-415. DOI: 10.1007/s10661-010-1465-9.

Reid GM, Contreras MacBeath T, Csatádi K. 2013. Global challenges in freshwater-fish conservation related to public aquariums and the aquarium industry. Intl Zoo Yearbook 47 (1): 6-45. DOI: 10.1111/izy. 12020 .

Sarkar U, Pathak A, Sinha R, Sivakumar K, Pandian A, Pandey A, Lakra W. 2012. Freshwater fish biodiversity in the River Ganga (India): Changing pattern, threats and conservation perspectives. Rev Fish Biol Fish 22 (1): 251-272. DOI: 10.1007/s11160-011-9218-6.

Schmid M, Köster O. 2016. Excess warming of a Central European lake driven by solar brightening. Water Resour Res 52 (10): 8103-8116. DOI: 10.1002/2016WR018651.

Shah SK. 2014. Water quality assessment of Mardi river by using water quality index. Bibechana 10: 100-107. DOI: 10.3126/bibechana.v10i0.7106.

Sharma RC, Singh N, Chauhan A. 2016. The influence of Physicochemical parameters on phytoplankton distribution in a headwater stream of Garhwal Himalayas: A case study. Egypt J Aquat Res 42 (1): 11-21. DOI: 10.1016/j.ejar.2015.11.004

Sharma S, Banjade S, Bhandari R. 2007. Impact of Khimti-I Hydropower Project in Nepal on the ecological status of river and fishermen's livelihood. Paper presented at the International Conference on Small Hydropower-Hydro Sri Lanka.

Shrestha J. 1981. Fishes of Nepal. Curriculum Development Centre, Tribhuvan University, Nepal.

Shrestha OH, Shreshta J. 2008. Seasonal food and feeding habits of Naziritor chelynoides (Mc Clelland) 1839 of Mardi Khola, Kaski, Nepal. J Nat Hist Mus 23: 98-107. DOI: 10.3126/jnhm.v23i0.1847.

Shrestha TK. 2008. Ichthyology of Nepal: A Study of Fishes of the Himalayan Waters. Vedams Books International, India.

Shrestha TK. 2019. Ichthyology of Nepal: A Study of Fishes of the Himalayan Waters. Vedams Books International, India.

Singh G, Agarwal NK. 2014. Fish assemblage structure and habitat use of the snow fed stream Assiganga-a major tributary of river Bhagirathi in Central Himalaya (India). Int J Aquat Biol 2 (6): 305-312. DOI: 10.22034/ijab.v2i6.126 
Strayer DL, Dudgeon D. 2010. Freshwater biodiversity conservation: Recent progress and future challenges. J North Am Benthol Soc 29 (1): 344-358. DOI: 10.1899/08-171.1.

Subba S, K Mahaseth V, R Subba B, R Bhusal D. 2020. Monthly dynamics of reproductive indices of Neolissochilus hexagonolepis (McClelland, 1839) and their relationship with Physico-chemical parameters along the mid-reaches of Tamor River, Nepal. Egypt J Aquat Biol Fish 24 (2): 239-247. DOI: 10.21608/ejabf.2020.80222.

Talwar PK, Jhingran AG. 1991. Inland Fishes of India and adjacent Countries (Vol. 2). CRC Press, United States.

Taylor GF, Weinhold M, Adams SB, Khatiwada NR, Bhattarai TN, Shakya S. 2014. Assessment of Water Resources Management \& Freshwater Biodiversity in Nepal, Final Report.

Ter Braak CJ, Smilauer P. 2002. CANOCO Reference Manual and CanoDraw for Windows User's Guide: Software for Canonica Community Ordination (version 4.5). Canoco, United States.

Tongnunui S, Beamish FW, Kongchaiya C. 2016. Fish species, relative abundances and environmental associations in small rivers of the Mae Klong River basin in Thailand. Agric Nat Resour 50 (5): 408-415. DOI: 10.1016/j.anres.2016.09.001.
Vaughn CC. 2010. Biodiversity losses and ecosystem function in freshwaters: Emerging conclusions and research directions. BioSci 60 (1): 25-35. DOI: 10.1525/bio.2010.60.1.7.

Virgilio LR, Ramalho WP, da Silva Silva JCB, da Silveira Suçuarana M, de Brito $\mathrm{CH}$, Vieira LJS. 2018. Does riparian vegetation affect fish assemblage? A longitudinal gradient analysis in three Amazonian streams. Acta Sci Biol Sci 40: e42562-e42562. DOI: 10.4025/actascibiolsci.v40i1.42562.

Wood JL, Belmar-Lucero S, Hutchings JA, Fraser DJ. 2014. Relationship of habitat variability to population size in a stream fish. Ecol Appl 24 (5): 1085-1100. DOI: 10.1890/13-1647.1.

World Wildlife Fund. 2021. One-third of Freshwater Fish Face Extinction and Other Freshwater Fish Facts. Retrieved 3rd Dec 2021.

WWF International. 2021. The World's Forgotten Fishes.

WWF Nepal. 2013. Chitwan Annapurna Landscape (CHAL): A Rapid Assessment. World Wildlife Fund Nepal, Kathmandu, Nepal.

Xu H, Liu S, Xie Q, Hong B, Zhou W, Zhang Y, Li T. 2016. Seasonal variation of dissolved oxygen in Sanya Bay. Aquat Ecosyst Health Manag 19 (3): 276-285. DOI: 10.1080/14634988.2016.1215743 